\title{
A note on Vico and Lotman: Semiotics as a "science of the imagination"
}

\author{
Marcel Danesi \\ Victoria College, University of Toronto, \\ Toronto, Ontario M5S 1K7, Canada \\ e-mail: marcel.danesi@utoronto.ca
}

\begin{abstract}
The Italian philosopher Giambattista Vico foreshadowed many of the ideas currently being entertained by the modern cognitive and human sciences. By emphasizing the role of the imagination in the production of meaning, Vico showed how truly ingenious the first forms of representation were. His view that these forms were "poetic" is only now being given serious attention, as more and more linguists and psychologists come to realize the role of metaphor in the generation of abstract systems of representation. The Estonian semiotician Yuri Lotman espoused a basically similar view, highlighting the role of the poetic imagination in the generation of the textuality that holds cultures together in meaningful ways. A comparison of these two exceptional thinkers has never been entertained. This note aims to do exactly that. Specifically, it takes a first glimpse at the parallels of thought and method that inhere in the main works of these two ground-breaking thinkers. Such a comparison will establish a theoretical framework to make semiotics a true "science of the imagination". It will show that semiosis and representation are not tied to any innate neural mechanisms, but rather to a creative tendency in the human species to literally "invent itself".
\end{abstract}

\section{Introduction}

Since the 1970s there has been a noticeable increase of interest and writing on two previously-neglected figures in the history of ideas the Italian philosopher Giambattista Vico (1668-1744) and the Estonian semiotician Yuri Lotman (1922-1993). The reason for this is, 
arguably, that the modern human and cognitive sciences are finally "catching up" to their ideas. Both were interested, fundamentally, in unraveling the raison d'être and origins of meaning structures in the human species and in how these constituted the source of cultural systems. Both saw the imagination as the primary faculty of mind underlying the invention of these very structures. Vico called it fantasia; Lotman characterized it as a kind of energy. Simply put, for Vico and Lotman Homo sapiens was "sapient" because it was, in essence, an imaginative creative species. Both went against the Western tradition of studying the human mind "objectively" or "scientifically", arguing that only an orientation based on a study of the imagination would provide truly meaningful insights into the nature of human knowledge and of how it is literally created by the mind.

To the best of my knowledge, no one has ever entertained a comparison of these two ground-breaking thinkers. That is the purpose of the present brief note. It is unlikely that the great Estonian semiotician ever read Vico. So, the comparison to be carried out here is not the typical one of showing the purported influence of one thinker upon another. Rather, the perspective to be adopted in this essay inheres simply in highlighting the remarkable "isomorphisms" that can be detected in the work of Vico and Lotman. Specifically, the comparison will be carried out within the framework of three fundamental notions, named by Vico as fantasia, ingegno, and memoria (see Verene 1981, Mooney 1985, Bedani 1989, Danesi 1993 for detailed discussions of these notions). All citations from Vico's New Science - his main work - are taken from T. G. Bergin and M. H. Fisch's 1984 revised translation of the third edition published in 1744. Allusions to Lotman's ideas are based on the following works: Lotman (1977, 1980, 1984, 1990, 1994), Lotman and Uspenskij (1973, 1978), and Ivanov, Lotman, Pjatigorski, Toporov, and Uspenskij (1998).

\section{Fantasia}

In Vico's times, Cartesianism dominated the academic scene of the day, causing the older tradition, centered on the study of language and literature, to lose ground to an emphasis on mathematics, critical philosophy, and the sciences. Vico warned that an emphasis on logic was ultimately counterproductive. Natural learning, he emphasized, followed a developmental route that started from concrete modes of thinking, progress- 
ing only gradually, and with significant effort, to rational modes. In this developmental scenario, Vico viewed the imagination, which he called the fantasia, as the central force in knowledge-acquisition. His magnum opus of 1725, La scienza nuova (The New Science, Vico 1984 [1725]) is, in fact, characterizable as a "science of the imagination", as Verene (1981) aptly calls it. This work should have guaranteed him a wide readership and a broad range of responses. But it went virtually unnoticed until the latter part of the twentieth century as a truly remarkable treatise on the mind, when the human and cognitive sciences finally started to take serious notice of the kinds of things Vico was thinking and writing about over two and a half centuries ago. His ideas on the nature of human rationality, and on how it must have originated in the imagination, are not only highly compatible with current thinking in some of the modern sciences, but they are also highly suggestive of future directions for these sciences to pursue. The idea that cognition is an extension of bodily experience, a kind of abstracted sensoriality, which is starting to receive serious and widespread attention by some psychologists and linguists, is, as a matter of fact, the unifying principle that Vico utilized to tie together all the thematic strands that he weaved throughout The New Science.

Vico argued that this extension is accomplished through the workings of the imagination. He saw it as the mental faculty that generated rational thought, language, and ultimately, culture. He sought access to its workings, not by means of a Cartesian-type method of observation and analysis, but through a study of the symbolic artifacts - especially humanity's first words and myths - to which the primordial imagination gave birth. For Vico, Descartes' "spectator theory" of knowledge was of little value, for he did not believe in a world as an object to be studied independently of the individual's involvement in it. The purported "facts" that scientists discovered were, for Vico, no more than "artifacts" of the mind. The reason why we are so convinced by such artifacts is that we ourselves have invented them. As an alternative to Descartes' Cogito ergo sum perspective, Vico proposed one by which humans first feel, then vaguely perceive what they have felt, and, finally, attempt to develop distinct ideas from their perceptions. So, in counterposition to Descartes' Latin maxim, Vico's perspective could perhaps be phrased as Sentio ergo sum.

The cornerstone notion of The New Science, 'poetic wisdom', can be found in Book Two. There, Vico's objective was to discuss the first form of mentality - the innate universal capacity to think "poeti- 
cally", i.e. iconically and sensorially. The most important feature of the poetic mind is that it is highly metaphorical and mythological. It is, in other words, totally dependent on the images generated by bodily experiences as they are encoded and shaped by the imagination. From this "poetic" state of mind the first human cultures took shape, developing the first institutions, especially religious, burial, and marriage rites. The organization of early cultures is, thus, universally "poetic;" i.e. it is based upon, and guided by, conscious bodily experiences that have been transformed into generalized ideas by the human fantasia.

The distinguishing feature of the primordial form of human consciousness is that it allows us literally to "imagine" stimuli that are no longer present for the sensory system to react to in its biologicallyprogrammed way. The thought units that result from these images are iconic signs - units of thought that stand for their referents in direct ways. These signs also allow humans to think about their referents away from their contexts of occurrence. The fantasia can thus "create" new realities totally within the confines of mental space - hence the meaning of imagination as a creative faculty. By not being constrained to a stimulus-response environment, the imagination has bestowed upon humans the capacity to "imagine" fictional (context-free) beings, objects, and events. The fantasia thus liberates human beings from the constraints imposed on all other organisms by biology. As Verene (1981: 101) puts it, the imagination allows humans "to know from the inside" by extending "what is made to appear from sensation beyond the unit of its appearance and to have it enter into connection with all else that is made by the mind from sensation".

The debate on the imagery goes back to Plato, who separated the image (eikon) from the idea (eidos). This set in motion the tendency to view rational thought as separate from mental imagery and as a more powerful shaper of cognition. Descartes (1637) reinforced this notion by claiming that mental images proceed without logic, and so cannot be studied scientifically. The Cartesian view ignores, of course, the Renaissance tradition of ingenium and the fact that even Plato used myths or likely narratives as the primary means for gaining access to an understanding of "reality". Paradoxically, as Verene (1981) has pointed out, Descartes' own style of presentation unfolds in the form of highly suggestive and creative imagery. What Plato, Descartes, and all philosophers fixated on the idea forgot, according to Vico, was that mental imagery is essential to thought. In fact, he makes the ability to 
form and extend images a universal feature of cognition. The fantasia's image-making capacity is a primordial power of the human mind that makes cognition itself possible.

Remarkably, in the work of Lotman it is fairly easy to detect the same Vichian notion that the basic form of mentality is poetic - a form which he characterizes as energeia, a kind of "creative potency" that undergirds every act of meaning-making, from the simple invention of words to the creation of elaborate artistic texts. As Torop (1999: 11) aptly puts it, Lotman's notion of creative potency is at the basis of his corollary notion of modeling - a view that has started to influence semiotic methodology in systematic ways (e.g. Cáceres Sánchez 1997, Kull 1999, 2000, Torop 1998, Sebeok 1998, Sonesson 1998, Danesi and Perron 1999, Sebeok and Danesi 2000). Essentially, as I read Lotman with "Vichian eyes", I see his notion of creative modeling as fantasia. For both Vico and Lotman this creative faculty is the force that links the biosphere with the semiosphere in all acts of representation (see also Cornwell 1992, Kristeva 1994, Mandelker 1994, Kull 1998, and Portis-Winner 1999 on the Lotmanian notion of semiosphere).

The semiosphere is "the smallest functioning mechanism" (Lotman 1990: 125) of human cognition that allows the mind to conceptualize basic experiences of sensation. Like the great biologist Jakob von Uexküll (1909), Lotman finds a constant point of contact between biology and human mental activity. Uexküll argued that every species had different inward and outward lives. The key to understanding this duality could be found in the anatomical structure of the species itself and in the kind of innate modeling systems it possessed. Animals with widely divergent anatomies and modeling systems do not have access to the same kinds of experiences and perceptions (Sebeok 1990, 1994). For Lotman, the ability to convert biospheric reality into semiospheric reality is the reason why, over time, the human species has come to be regulated not by force of natural selection, but by the "force of history". As opposed to Nature, culture is everywhere meaningful, everywhere the result of modeling structures that seek to give meaning, order, and continuity to experience. The aim of semiotics is, therefore, to examine, first and foremost, the origin and evolution of the signifying properties of these structures. And if there is any one finding of semiotic research that stands out from all others it is that, despite great diversity in the world's sign systems, the difference is more one of detail than of substance. These systems serve the original 
functions for which they were designed, revealing strikingly similar patterns throughout the world.

The semiosphere emerges as a response to a specific human need to model and interpret the dynamic flux of the world in the form of signs. Of all the modeling systems that characterize human semiosis, no other is so powerful and so unique as is language. Language is the ultimate achievement of semiosis. But, as Lotman reminds us cogently in virtually all his writings, it is highly interconnected to nonverbal modes of modeling and communication. Indeed the essence of language is poetry. It is the same type of modeling - creative simulation - that characterizes drawings, music, artifacts and other nonverbal models of the world that people make and use routinely. Together with verbal models, they constitute one huge Text (Lotman 1990: 377).

Thus it is that Vico and Lotman have an identical point-ofdeparture in the study of human meaning-making — the imagination. In both, this is seen as a quality of mind that produces poetic forms that unite the verbal and nonverbal domains into a holistic Gestalt of interconnected meanings. This "dialogue" between Nature and the human mind, as Lotman so often called it, is the fundamental form of human cognition. It constitutes, as Vico termed it, a poetic wisdom that is found throughout time and across cultures.

\section{Ingegno}

Given the role of fantasia or energeia in spurring the human mind to create its own world of thought, the question becomes: How does one go from imagining to actually producing signifying structure? For Vico, as I read him, the answer is to be found in a second unique ability of human mentation - the ingegno "ingenuity", "invention", the faculty of the conscious mind that organizes the poetic forms produced by the fantasia into meaningful structures. Whereas the fantasia is an epiphenomenal product of brain activity, linking body and mind, the ingegno is a derivative of the fantasia - a kind of "epiepiphenomenal" activity, stimulating the mind to carry out its creative handiwork. It is thus not connected directly to neural processes, operating totally within mental space as it configures and creates models of world events. "Making sense" is a product of the ingegno as it imposes pattern onto the images that the fantasia creates in mind-space. The brains of all animals have the capacity to form memorable im- 
ages. This is a survival function. But animals lack the ability to transform their images into invented structures. This inheres in the agreements or resemblances that the human mind alone is capable of making between the images produced by the brain and their corresponding sensory units as registered by the body. As Vico phrases it: "The human mind is naturally inclined by the senses to see itself externally in the body" (Vico 1984 [1725]: 236).

The ingegno is, therefore, the source of syntax in language and of narrative structure in verbal discourse. It was at the creative nucleus of the earliest myths that humanity literally invented. Laws, scientific theories, fictional narrations, etc. are all traceable to the ability of the ingegno "to beget" - the word ingegno derives from Latin in "in" + gignere "to beget". Whereas fantasia corresponds to what Charles Peirce (1839-1914) called firstness, then ingegno corresponds instead to what he called secondness. The same view is found in Lotman. For the Estonian semiotician, the ability to make purely invented models of the world is a derivative of the fundamental creative energy of the human mind. This is accomplished by an innate ability to shift from primary poetic modeling to secondary more abstract modeling. This produces textuality in human affairs, an interconnected form of representation that bestows a sense of wholeness and unity upon signification. Lotman (1990: 138) puts it as follows: "The entire space of the semiosphere is transected by boundaries of different levels", which in turn create "a multileveled system".

It is within such a multileveled system that symbolic activity thrives, transforming human consciousness into one that is no longer only attentive to sensible properties and to spatiotemporal and relational patterns, but also to all kinds of referents (actual and potential) in and of themselves within the confines or boundaries of the semiosphere, as Lotman calls them. Symbolicity is what creates cultural textuality. Drawings, narratives, theories, conversations, etc. are thus all interconnected symbolically, displaying similarities in structure, signification, and referentiality. Texts incorporate the structural properties of the symbols with which they are constructed, and deliver conceptually equivalent meanings. This allows people to envision distinct bits of information and real-world phenomena as integrated wholes, rather than as disparate elements of consciousness. 


\section{Memoria}

The final question that Vico asks is: How do we remember the meaningful signifying structures that the fantasia brought into existence in the first place? Vico answers this question with the notion of memoria - the faculty of mind that can detect the latent and original meaning structures of forms by simple exposure to them. This innate "sense of and for meaning" is not conscious, but embedded in the fantasia itself. Memory is thus a form of imagination itself. The creative imagination, or fantasia, is the faculty that allows us to convert our sense impressions into images; the memoria is the faculty that makes these images part of the very structure of the human brain. Thomas Sebeok (1987) aptly characterizes the operation of this level of mind as an "affective modeling of knowledge". Susanne Langer (1948) has convincingly argued that, at this level of cognition, we recall the world through "feeling", i.e. we "feel" that the world has a structure. It is at this mnemonic level that one can talk of "imaginative universals", as Vico calls them (Verene 1981: 65-95, Mooney 1985: 227-230). These are connected to each other through the medium of metaphor, which is itself the handiwork of the ingegno. The particular characteristics of this metaphorically-fabricated mental universe constitute the source of differences among persons and among cultures. Although it evolved out of the fantasia, it has come to be the dominant form of mentality.

For Vico metaphor is a mental capacity that results from the interaction of the fantasia and the ingegno. As these two deep-level faculties perform their functions in tandem, they generate metaphor, which can be defined as a kind of epiphenomenal amalgam of fantasia and ingegno. For Vico metaphor is, therefore, a feature of the mind, not of language. It does, of course, surface constantly in discourse in the form of verbal metaphors and other verbal tropes (Lakoff and Johnson 1980, 1999, Gibbs 1994, Goatley 1997); but it can also manifest itself in other ways, such as in visual representational media (e.g. Winner 1982, Hausman 1989).

Vico referred to the operations of the metaphorical mind as poetic logic. He called the first speakers "poets", which etymologically means "makers". He defined metaphor as a "fable-making" capacity emerging from poetic logic that creates likenesses among percepts and perceptual models to create new, and therefore, context-free, associa- 
tions. In this new world of the mind even "inanimate bodies" can be brought to life:

All the first tropes are corollaries of this poetic logic. The most luminous and therefore the most necessary and frequent is metaphor. It is most praised when it gives sense and passion to insensate things, in accordance with the metaphysics above discussed, by which the first poets attributed to bodies the being of animate substances, with capacities measured by their own, namely sense and passion, and in this way made fables of them. Thus every metaphor so formed is a fable in brief (Vico 1984: 404).

Phylogenetically, the metaphorical capacity emerged to convert images of the fantasia into memorable concepts. The primordial function of metaphor inhered in what Verene (1981) calls an "isness" relation. Traditionally, metaphor is understood as being tied to analogy, i.e. as finding something to be "like" something else. For Vico, on the other hand, the primordial operation of the metaphorical capacity creates an "isness" among things. Vico claimed that Jove was the first name created by humans as they became conscious of the first thundering sky (Vico 1984 [1725]: 374-384). Once this sky was called Jove, all other experiences of the same phenomenon can be "found again" in this name. Jove is, as Verene (1981) points out, our first imaginative universal, and thus a part of memoria. Something had come into existence, and this led to a conscious separation of the sky from the earth, of the divine from the world. From their common perception of Jove the first conscious humans learned to make sense together. Without the power of the fantasia, all could have quickly lapsed back into nothingness.

As metaphorized concepts become more and more removed from their deep-level origins, settling into their new memory system, they generate highly abstract structures on their own. Free from sensory control, these structures gradually come to dominate purposeful thinking. The mind's cognitive system is a truly powerful one. It can be projected onto the external world of reality to partition it, organize it, classify it, and explain it. These projections of the mind have produced our symbolic and cultural systems - our institutions, scientific theories, laws, etc. The structure of these systems, therefore, can be used to investigate the structure of our memoria. This is Vico's verumfactum principle, which posits that we can know only what we ourselves have made (e.g. Mondolfo 1969, Garin 1972, Verene 1981: 3664). Vico's motivation for this notion comes from his observation that: "the world of civil society has certainly been made by men, and 
that its principles are therefore to be found within the modifications of our own human mind" (Vico 1984 [1725]: 331). Vico warns us throughout the NS that we must never forget how our dominant abstract mode of conceptual thinking originated, and that we should not ignore the fact that we continue to rely on our imagination when our abstract mind fails us: "For when we wish to give utterance to our understanding of spiritual things, we must seek aid from our imagination to explain them and, like painters, form human images of them" (Vico 1984 [1725]: 404).

If there is any notion in Lotman that, to my mind, is totally isomorphic with the Vichian memoria it is his very definition of culture as a text, which is, in effect, one huge collective memory system, displaying all the properties of neurological memory. Memoria, which corresponds to Peircean thirdness, is "dialogical" in the sense that it unfolds as an inner dialectic between individual and history. As an example, consider the use of the rose as a symbol for love in Western culture. It originated in the imagination as a way of understanding the feeling of love because its physical features [sweet smell], [red color], [plant], are perfect forms for coming to grips with this emotion. As this form passed into memoria it now stimulates a constant dialogue as to what it entails in signifying terms. In effect, this symbol "generates an image of the historical past, which culture transfers into the past and which, like an equal partner in a dialogue, affects the present" (Lotman 1990: 272).

\section{The cultural cycle}

It is in Book Four of The New Science where Vico develops his theory of the corso of history in terms of the three ages - the "divine", the "heroic", and the "human". He portrayed each age as manifesting its own particular kind of customs, laws, language, and even human nature. He did not, however, see this historical sequence as necessarily irreversible. So, in Book Five, he elaborated the idea of the ricorso, the return of an earlier age in the life of a culture. The course of humanity, according to Vico, goes from a poetical nature, through a heroic one, to a rationalistic one. Each age has its own kind of mentality and language. The poetic mentality, for instance, generates myths; the heroic one, legends; and the rational one, narrative history. Rationality, according to Vico is humanity's greatest achievement. But, unlike 
Cartesian philosophers, he did not see it as an innate "given". He considered to be a point-of-arrival, that was achievable only in a social ambiance. Human beings do not inherit rationality from their biological legacy. Stripped of culture, which is a collective memoria, human beings would be forced resort to their poetic, or corporeal, imaginations to make sense of the world all over again.

Vico thus proposed a cyclical theory of human cultural evolution, according to which human societies progress through a series of stages from barbarism to civilization and then back to barbarism. The term "barbarism" in Vico refers simply to a primitive stage of civilization. In the first stage - which he called the "age of the gods" - religion, burial rites, the family, and other basic institutions emerge to lay the foundations of human culture. He called this primordial phase of humanity the age of the "gods", because he saw the first reflective humans as being filled with fear of natural phenomena such as thunder and lightening. Not possessing the knowledge to understand or "explain" such environmental events, the first humans ascribed them to awesome and frightful "gods" or "divine" creatures - hence the designation "age of the gods". In the succeeding "age of heroes", a dominant class of humans - the "heroes" of the evolving culture emerges typically to subjugate the common people. These are beings with great physical prowess who inspire fear and admiration in the common people. The latter typically ascribe divine powers to these "nobles". After a period of domination, a third stage — the "age of humans" - invariably takes shape in which the common people rise up and win equality; but in the process society begins to disintegrate as it returns to a more vile and violent form of barbarism (rational or reflective barbarism). This, according to Vico, is the natural "course" of human civilized cultures - a course that is not linear and endlessly progressive, but cyclical and finite. Cultures are born and cultures die. They do not go on forever.

The key to understanding cultural evolution is language, because it constitutes the primary mental means by which humans encode their thoughts and, therefore, can come together in order to help us think collectively. By studying the language of the people living during a specific age, Vico claimed, the scientist should be able to reconstruct the forma mentis of that people. This was, of course, Lotman's pivotal view as well. Indeed, he compared culture to a linguistic system, a kind of "outer reflection" of the structural properties of linguistic systems. Like Vico, Lotman also saw the first form of language as highly 
poetic (iconic). It is only in cultural contexts that humans speak a vernacular, literal language.

Vico argued for this three-stage historical progression primarily on the basis of the etymology of our common word-concepts. He persuasively demonstrated that words start out as concrete, iconic Gestalten based on our perceptions of the referents. Then metaphor - the innate universal ability to make connections among referents-transforms this sensorially-based meaning-universe into a conceptual one: i.e. one in which the referents of iconically-formed words are connected into generalized ideas. Finally, as cognition becomes increasingly more conceptual through the workings of the metaphorical capacity, the referents of the word-concepts also become increasingly more abstract and removed from their perceptual origins. Lotman, too, showed that the study of history is essentially a study of the meaning structures that result from a semiosis between body, mind, and culture across time.

\section{Semiotics as a science of the imagination}

In my view, the integration of Vico and Lotman will allow semiotics to develop a truly powerful investigative method for unraveling one of the greatest conundrums of all time: How did the mind, language, and culture come into existence? Their search for an answer to this riddle led each one, in his own way, to what is arguably the most important discovery of all time - the "poetic mind". And, as with many of their ground-breaking ideas, it is only in recent times that this notion called the "savage mind" by Lévi-Strauss (1962) — has started to receive widespread attention.

Lotman has already led the way in transforming semiotics into a "science of the imagination". But his view of scientific inquiry still creates problems among Western scientists for the simple reason that, in Western culture, the term science has always been synonymous with the "objective" knowledge of "facts" of the natural world, gained and verified by exact observation, experiment, and ordered thinking. The starting point for scientific objectivism is Ancient Greece, when, ever since Aristotle, Western science has come to embrace the idea that the physical universe is a great machine operating according to natural laws. Aristotle laid the foundations for the experimental investigation of matter by claiming that these laws were determinable ob- 
jectively by human reason. The term science in a Vichian-Lotmanian framework would have nothing to do with this traditional notion. For both scholars, we can know only what we ourselves have made, including science. The "laws" of Euclidean geometry, for instance, are not present in the universe in the way that we have specified them. Rather, they constitute humanity's cognitive strategy for organizing and rationalizing our visual perceptions of space.

Anything that humans have themselves made, and institutionalized culturally, can be designated as "artifactual". The object of a semiotics, as Lotman has showed, is to study the artifactual world, for it is through an investigation of all kinds of human "artifacts", from myths to languages, that the nature of human thought will reveal itself. When we strip the mind of its rationalized symbols and codes, then we are left with a form of perception and memory generated by a primordial fantasia. This produces a language that is grounded on concrete modes of thought and perception that reverberate constantly in the corners of the mind. As Verene (1981: 123) has observed, Vico claimed that thunder, for instance, must have had a traumatic effect on the emerging consciousness of our hominid ancestors. That effect is being "sounded" over and over in the deepest layers of our modern minds in our symbols and other artifacts.

This radically new way of thinking about science has substantial implications and ramifications for semiotics and the other human sciences, and can constitute a common grounding and unifying foundation for them in the future. The Vichian-Lotmanian model of mind offers concrete suggestions for drafting a research agenda that contains the following essential components:

- The essence of mind is the fantasia. Access to this feature can be gained by studying the products of the mind's poetic structure.

- The ingegno is the faculty that allows humans to express their fantasia. It is the source of metaphor, myth, and all the other products of human sense-making.

- The memoria is the textuality that emerges from this interplay between imagining and making of meaning.

- The signifying structures that we use in daily life (signs, texts, etc.) are end results of imaginative thinking.

Such agendas are actively being pursued by some contemporary scientists of the mind. The research on metaphor mentioned above (e.g. Lakoff and Johnson 1980, 1999) is a case-in-point. This goes 
contrary to the traditional view of mind as an information-processing device - a view that has led the human and cognitive sciences astray, away from a deeper understanding of the mind as a creator of meanings. Literature and myth, not artificial experimental studies, put on display our conceptions of ourselves and of the mental world which we have created for ourselves. These products reveal a form of thinking that gives pattern and continuity to human experience.

As Peirce (1931-1958, 1: 538) cogently argued, "Every thought is a sign". But, as he also wrote, "Not only is thought in the organic world, but it develops there" (Peirce 1931-1958, 5: 551). The relatively simple, nonverbal models that animals produce are natural forms that must fit "reality" sufficiently to secure the survival and "sanity" of the members of a species in their ecological niche. In human beings, however, the making of models transcends mere survival functions. And it is so pervasive and powerful that it often becomes very sophisticated indeed in the adult life of some individuals, as borne out by Einstein's testimonial, or by what we know about Mozart's or Picasso's ability to model intricate auditory or visual referents in their heads in anticipation of transcribing them onto paper or canvas. Language, symbols, art works, scientific theories, etc., as far as we know, are unique to anthroposemiosis. These make it possible for humans not only to represent immediate reality, but also to frame an indefinite number of possible worlds. The imagination-based modeling capacity in humans has led to what Bonner (1980: 186) calls "true culture", requiring "a system of representing all the subtleties of language", in contrast to "nonhuman culture". It is on this level, defined as tertiary, that nonverbal and verbal sign assemblages blend together in the most creative modeling system that Nature has thus far produced. To study this modeling system meaningfully, it is necessary to start with an investigation of the imagination itself for, as Vico and Lotman showed, it is the creative source of all the energeia that constitutes human mental and expressive activities.

\section{References}

Bedani, G. L. C. 1989. Vico Revisited: Orthodoxy, Naturalism and Science in the "Scienza Nuova". Hamburg: Berg.

Bergin, T. G. and Fisch, M. 1984. The New Science of Giambattista Vico. Ithaca: Cornell University Press. 
Bonner, J. T. 1980. The Evolution of Culture in Animals. Princeton: Princeton University Press.

Cáceres Sánchez, M. 1999. Scientific thought and work of Yuri Lotman. Sign Systems Studies 27: 46-59.

Cornwell, N. 1992. Lotman's semiosphere. Irish Slavonic Studies 13: 163167.

Danesi, Marcel 1993. Vico, Metaphor, and the Origin of Language. Bloomington: Indiana University Press.

Danesi, Marcel and Perron, Paul 1999. Analyzing Cultures: A Handbook and Reference Manual. Bloomington: Indiana University Press.

Garin, E. 1972. Ancora sul 'verum-factum' prima di Vico. Bollettino del Centro di Studi Vichiani 2: 59-61.

Gibbs, R. W. 1994. The Poetics of Mind: Figurative Thought, Language, and Understanding. Cambridge: Cambridge University Press.

Goatley, A. 1997. The Language of Metaphors. London: Routledge.

Hausman, C. R. 1989. Metaphor and Art. Cambridge: Cambridge University Press.

Ivanov, V. V.; Lotman, J. M.; Pjatigorski, A. M.; Toporov, V. N. and Uspenskij, B. A. 1998. Theses on the Semiotic Study of Cultures. Tartu: University of Tartu.

Kristeva, Julia 1994. On Yuri Lotman. PMLA 109: 375-376.

Kull, Kalevi 1998. Semiotic ecology: Different natures in the semiosphere. Sign Systems Studies 26: 344-369.

- 1999. On the history of joining bio with semio: F. S. Rothschild and the biosemiotic rules. Sign Systems Studies 27: 128-137.

- 2000. Organisms can be proud to have been their own designers. Cybernetics and Human Knowing 7: 45-56.

Lakoff, G. and Johnson, M. 1980. Metaphors We Live By. Chicago: Chicago University Press.

- 1999. Philosophy in the Flesh: The Embodied Mind and Its Challenge to Western Thought. New York: Basic.

Langer, S. K. 1948. Philosophy in a New Key. New York: Mentor Books.

Lévi-Strauss, C. 1962. La pensée sauvage. Paris: Plon.

Lotman, J. and Uspenskij, B. A. 1973 (eds.). Ricerche semiotiche. Torino: Einaudi.

Lotman, J. and Uspenskij, B. A. 1978. On the semiotic mechanism of culture. New Literary History 9: 211-232.

Lotman, J. M. 1977. Primary and secondary communication modeling systems. In: Lucid, D.P. (ed.), Soviet Semiotics. Baltimore: The Johns Hopkins University Press. 95-98.

Lotman, Y. 1980. Testo e contesto: Semiotica dell'arte e della cultura. Bari: Laterza.

- 1990. The Universe of the Mind: A Semiotic Theory of Culture. Bloomington: Indiana University Press.

- 1994. Cercare la strada. Modelli della cultura. Venezia: Marsilio. 
Mandelker, A. 1994. Semiotizing the sphere: Organicist theory in Lotman, Bakhtin, and Vernadsky. PMLA 109: 385-396.

Mondolfo, R. 1969. Il "verum-factum" prima di Vico. Napoli: Guida.

Mooney, M. 1985. Vico in the Tradition of Rhetoric. Princeton: Princeton University Press.

Peirce, C. S. 1931-1958. Collected Papers. Cambridge, Mass.: Harvard University Press.

Sebeok, Thomas A. 1987. In what sense is language a "primary modeling system? In: Broms, Henri and Kaufmann, R. (eds.), Proceedings of the 25th Symposium of the Tartu-Moscow School of Semiotics. Helsinki: Arator, 67-80.

- 1990. Essays in Zoosemiotics. Toronto: Toronto Semiotic Circle Monograph Series.

- 1994. Signs: An Introduction to Semiotics. Toronto: University of Toronto Press.

- 1998. The Estonian connection. Sign Systems Studies 26: 20-41.

Sebeok, Thomas A. and Danesi, Marcel 2000. The Forms of Meaning: Modeling Systems Theory and Semiotics. Berlin: Mouton de Gruyter.

Sonesson, Göran 1998. The concept of text in cultural semiotics. Sign Systems Studies 26: 83-114.

Torop, Peeter 1998. Semiotics in Tartu. Sign Systems Studies 26: 9-13.

- 1999. Cultural semiotics and culture. Sign Systems Studies 27: 9-23.

Uexküll, Jakob von 1909. Umwelt und Innenwelt der Tierre. Berlin: Springer.

Verene, D. P. 1981. Vico's Science of Imagination. Ithaca: Cornell University Press.

Vico, Giambattista 1984 [1725]. The New Science. Transl. from the 3rd ed. [1744] by T. G. Bergin and M. H. Fish. Ithaca: Cornell University Press.

Winner, E. 1982. Invented Worlds: The Psychology of the Arts. Cambridge, Mass.: Harvard University Press.

\section{Заметки о Вико и Лотмане: семиотика как "наука воображения"}

Итальянский философ Джамбаттиста Вико предвосхитил многие идеи, которыми питаются современные когнитивные и гуманитарные науки. Подчеркивая роль воображения в производстве значений, Вико показал всю выразительность первых форм репрезентации. Его оценка этих форм как “поэтических" привлекла серьезное внимание только сейчас, когда все большее число лингвистов и психологов начинают осознавать роль метафоры в порождении абстрактных систем репрезентации. Юрий Лотман придерживался сходных взгля- 
дов, подчеркивая важность поэтического воображения в порождении текстуальности, связуюшей воедино культуру. Сравнение этих двух выдающихся мыслителей никогда не проводилось. Именно оно является целью данной заметки. В ней предприняты первые шаги по выявлению параллелизма мышления и метода основных работ этих двух новаторов. Такое сравнение создаст теоретическую основу преврашения семиотики в настоящую “науку воображения". Оно покажет, что семиозис и репрезентация связаны не с какими-либо врожденными нейромеханизмами, но с творческой тенденцией “самоизобретения”, присущей человеческому роду.

\section{Vico ja Lotman: semiootika kui "kujutlusteadus"}

Itaalia filosoof Giambattista Vico oli paljude tänapäeval kognitiivsetes ja humanitaarteadustes käibivate ideede eelkäijaks. Rõhutades kujutlusvõime tähtsust tähenduse tekitamises, näitas Vico esmaste representatsioonivormide olulisust, määratledes neid kui "poeetilisi". Alles kaasajal, kui üha suurem hulk lingviste ja psühholooge teadvustavad metafoori osa abstraktsete representatsioonisüsteemide loomisel, on hakatud sellesse vaatesse tõsisemalt suhtuma. Ka Juri Lotman oli sarnasel seisukohal, kriipsutades alla poeetilise kujutlusvõime olulisust kultuuri siduva tekstuaalsuse genereerimisel. Neid kahte väljapaistvat mõtlejat ei ole kunagi võrreldud ja see ongi meie artikli eesmärgiks. Tuuakse välja parallelism nende kahe novaatori mõttetegevuses ja meetodis. Selline võrdlus loob teoreetilise aluse semiootika muutmisel tõeliseks "kujutlusvõime teaduseks" ja näitab, et semioosist ja representatsiooni ei seo kaasasündinud neuromehhanismid, vaid inimloomusele omased loomingulise "eneseleiutamise" tendentsid. 